\title{
BIMBINGAN TEKNIS PENGOLAHAN TELUR ASIN REMPAH PANGGANG DI PKK RUHUY RAHAYU DESA BENTOK KAMPUNG KECAMATAN BATI - BATI KABUPATEN TANAH LAUT PROVINSI KALIMANTAN SELATAN
}

\section{Roasted Salted Eggs with Spices Processing Technical Guidance at PKK Ruhuy Rahayu Bentok Kampung Village, Bati - Bati District, Tanah Laut Regency, South Borneo Province}

\author{
Sugiarti*, Fitriani, Siti Dharmawati
}

Program Studi Peternakan, Fakultas Pertanian, Universitas Islam Kalimantan MAB, Universitas

Islam Kalimantan MAB, Banjarmasin

Article history

Received: Apr 28, 2021

Accepted: Jul 12, 2021

* Corresponding author:

E-mail:

atiksugiarti369@gmail.com DOI: https://doi.org/10.465 49/igkojei.v2i2.220

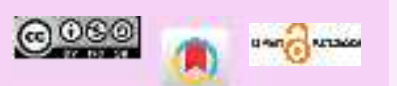

\begin{abstract}
Bentok Kampung Village is one of the villages in Bati-Bati District, Tanah Laut Regency, which possessed a considerable amount of duck population. The villagers who are members of the Ruhuy Rahayu PKK do not know much about innovations in processing duck salted eggs. This activity aims to introduce innovation in preserving duck eggs with the addition of spices. This activity started with theoretical training with classroom methods and hands-on practice carried out by partners under the guidance of the activity promotor team. The enthusiasm of the participants is was quite good which was reflected in the high number of participants and their punctuality of attendance. The attendance level of participants in both the counseling and brainstorming activities reached 90-100\% of all PKK members. The roasted salted duck eggs with spices produced have a distinctive taste compared to the ones which were just boiled. The roasted spiced salted roasted egg has a less wet texture and is preferred because it tastes more savory and can last longer because of the reduced water content. Conclusion: participants managed to understand well the entire series of activities and the participation rate of participants was very good with a nearly $100 \%$ attendance rate.
\end{abstract}

Keywords: Processing, Roasted spiced salted eggs, Bentok Kampung Village

\section{ABSTRAK}

Desa Bentok Kampung merupakan salah satu desa yang ada di Kecamatan Bati-Bati Kabupaten Tanah Laut dengan populasi itik yang tinggi. Masyarakat Desa Bentok Kampung yang tergabung dalam PKK Ruhuy Rahayu belum banyak mengetahui inovasi dalam pengolahan telur asin itik. Kegiatan ini bertujuan untuk memperkenalkan inovasi pengawetan telur itik dengan penambahan bahan rempah. Kegiatan ini diawali pelatihan teoritis dengan metode kelas dan praktek langsung yang dilaksanakan oleh mitra dengan bimbingan tim pengusul kegiatan. Antusiasme peserta cukup baik yang tercermin dari jumlah dan ketepatan waktu kehadiran yang tinggi. Kehadiran peserta dalam kegiatan penyuluhan dan curah pendapat mencapai 90-100 \% dari seluruh anggota PKK. Telur asin itik rempah panggang yang dihasilkan memiliki cita rasa yang khas dibandingkan dengan yang hanya direbus. Telur asin itik rempah panggang memiliki tekstur tidak terlalu basah dan lebih disukai karena rasanya yang lebih gurih dan bisa lebih tahan lama karena adanya pengurangan kadar airnya. Kesimpulan: peserta berhasil memahami dengan baik seluruh rangkaian kegiatan 
dan tingkat partisipasi peserta sangat baik dengan tingkat kehadiran berkisar $100 \%$.

Kata Kunci: Pengolahan, Telur asin rempah panggang, Desa Bentok Kampung

\section{PENDAHULUAN}

Telur mudah mengalami kerusakan, baik kerusakan alami, kimiawi maupun kerusakan akibat serangan mikroorganisme melalui pori-pori telur. Upaya untuk meningkatkan teknologi pengolahan hasil ternak yang berupa telur itik adalah dengan pengawetan yang bertujuan untuk mempertahankan mutu telur (Theresia et al., 2014). Salah satu usaha pengawetan telur adalah dengan melakukan pengasinan. Bahan baku yang umum digunakan pada produksi telur asin adalah telur itik, karena memiliki pori-pori kerabang yang besar sehingga garam lebih mudah berpenetrasi ke dalam telur. Kuning telur dari telur itik lebih mudah terbentuk tekstur masir dan berminyak saat dibuat telur asin dibandingkan dengan telur yang lain (Sari, 2013).

Pada umumnya masyarakat membuat telur asin dengan cara yang sederhana yaitu dengan memeram telur ke dalam larutan garam, ataupun dengan berbagai media lainnya seperti abu gosok, serbuk bata merah dan sebagainya dan belum banyak inovasi lainya. Salah satu inovasi yang dapat digunakan dalam pengolahan telur asin adalah dengan penambahan rempah sehingga selain dapat memperlama daya simpan juga mampu menambah citarasa untuk meningkatkan selera konsumen, sehingga menambah pilihan pada produk pengolahan telur.

Desa Bentok Kampung merupakan salah satu desa yang ada di Kecamatan Bati-Bati Kabupaten Tanah Laut Provinsi Kalimantan Selatan. Jenis populasi ternak tertinggi di desa tersebut adalah itik dan sapi. Pemberdayaan Kesejahteraan Keluarga (PKK) Ruhuy Rahayu didirikan pada tahun 2020 di Desa Bentok Kampung. Anggota PKK Ruhuy Rahayu belum mengetahui inovasi dalam pengolahan telur asin itik, sehingga perlu dilakukan sosialisasi tentang inovasi pengolahan telur itik. Kegiatan ini bertujuan untuk meperkenalkan inovasi pengawetan telur itik dengan penambahan bahan rempah.

\section{METODE}

\section{PELAKSANAAN KEGIATAN}

Pengabdian pada masyarakat program peningkatan pemberdayaan masyarakat dilaksanakan di PKK Ruhuy Rahayu Desa Bentok Kampung Kecamatan Bati-Bati Kabupaten Tanah Laut Provinsi Kalimantan Selatan. Kegiatan dilaksanakan dari bulan Januari sampai dengan bulan April 2021.

Metode pelaksanaan kegiatan yang digunakan adalah sebagai berikut: a) Pelatihan teoritis (metode kelas) teknik pengolahan telur asin itik rempah panggang (Gambar 1a) dan b) Praktek langsung yang dilaksanakan oleh mitra (anggota PKK Ruhuy Rahayu) dengan bimbingan tim pengusul yang meliputi kegiatan penyiapan bahan sampai pengolahan (Gambar 1b). 
Indikator evaluasi kegiatan adalah sebagai berikut (1) Mitra mampu memilih bahan pembuatan telur itik asin yang berkualitas (2) Mitra mampu membuat telur asin rempah panggang, dimana mitra memperlihatkan peningkatan kemampuan sebelum dan setelah pelaksanaan kegiatan. Evaluasi dilakukan dengan kuesioner yang diisi oleh mitra.

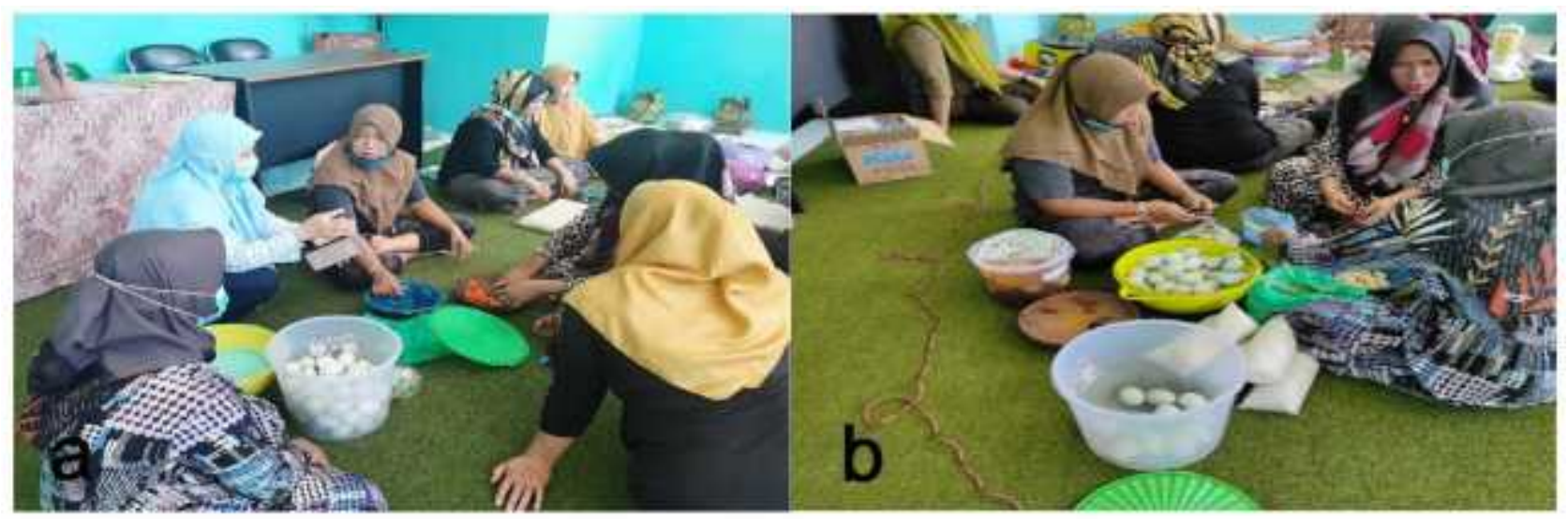

Gambar 1. (a) penyuluhan dan (b) praktek pembuatan telur asin rempah panggang

\section{PROSEDUR PEMBUATAN TELUR ASIN REMPAH PANGGANG}

Bahan-bahan yang digunakan adalah 15 butir telur itik, 600 gr garam, 1,3 liter air, 10 lembar daun salam, 3 batang serai dimemarkan, $10 \mathrm{~cm}$ lengkuas, dimemarkan, $10 \mathrm{~cm}$ jahe, dimemarkan dan 8 siung bawang putih, dimemarkan.

Cara membuat: 1) Telur dicuci bersih, kemudian diamplas seluruh permukaan kulitnya secara perlahan; 2) Garam dan rempah direbus sampai garam larut, kemudian didinginkan sesuai dengan suhu ruang; 3) Telur di dalam toples direndam sempurna dengan larutan yang telah disiapkan dan disimpan selama 2 atau 3 minggu; 4) Telur ditiriskan dan kemudian di oven \pm 1 jam dengan suhu $80^{\circ} \mathrm{C}$.

\section{HASIL DAN PEMBAHASAN}

Antusiasme peserta dalam kegiatan ini sangat tinggi yang tercermin dari jumlah kehadiran dan ketepatan waktu kehadiran peserta. Kehadiran peserta dalam kegiatan penyuluhan dan curah pendapat (brainstorming) antara 90-100\%.

Telur asin itik rempah panggang tidak terlalu basah dan lebih terbukti disukai karena rasanya yang lebih gurih dan bisa lebih tahan lama karena adanya pengurangan kadar airnya (Gambar 2). Telur asin itik rempah panggang yang dihasilkan memiliki cita rasa yang berbeda dibandingkan dengan telur asin itik rempah rebus. Telur asin yang berkualitas memiliki ciri-ciri rasa asin yang cukup, kuning telur berwarna kemerah-merahan dan terkesan berpasir, dan memiliki umur simpan yang lama (Suprapti, 2002). Kualitas dari telur asin ditentukan oleh beberapa faktor diantaranya bahan baku telur yang digunakan, serta proses pembuatannya (Theresia et al., 2014). Bahan baku 
yang umum digunakan pada produksi telur asin adalah telur itik, karena memiliki pori-pori kerabang yang besar sehingga garam lebih mudah berpenetrasi ke dalam telur. Kuning telur dari telur itik lebih mudah terbentuk tekstur masir dan berminyak saat dibuat telur asin dibandingkan dengan telur yang lain (Sari, 2013).

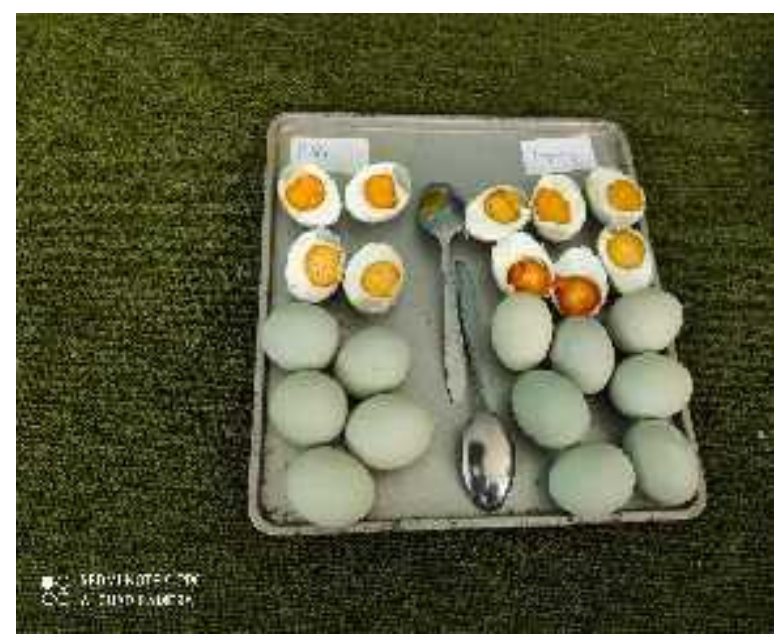

Gambar 2. Hasil dari pembuatan telur asin rempah panggang

Penambahan rempah-rempah dalam telur asin merupakan salah satu cara untuk memperpanjang daya simpan telur asin dan untuk menambah rasa pada telur asin tersebut, selain dari rasa asin karena adanya penambahan garam. Rempah-rempah seperti bawang putih, laos, sereh dan daun salam merupakan bumbu penyedap rasa alami yang banyak mengandung zat-zat kimia aktif yang bermanfaat untuk tubuh selain memberikan rasa yang lebih digemari konsumen (Nuun dan Sugiarto, 2019).

Hasil kegiatan memperlihatkan bahwa terjadi peningkatan pemahaman dan skill mitra setelah pelatihan, ditunjukkan dengan meningkatnya nilai posttest yang diberikan di akhir kegiatan, yang meningkat dari $75 \%$ menjadi 100\%. Mitra juga berhasil memahami dengan baik pemilihan bahan dan pengolahan telur itik asin rempah panggang.

\section{KESIMPULAN}

Mitra PKK Ruhuy Rahayu Desa Bentok Kampung, Kecamatan Bati-Bati, Kabupaten Tanah Laut, Provinsi Kalimantan Selatan berhasil memahami dan melaksanakan kegiatan inovasi pengawetan telur itik asin rempah panggang.

\section{UCAPAN TERIMA KASIH}

Ucapan terimakasih disampaikan kepada Yayasan dan Universitas Islam Kalimantan melalui Lembaga Penelitian dan Pengabdian pada Masyarakat yang telah mendanai kegiatan pengabdian kepada masyarakat Program Peningkatan Pemberdayaan Masyarakat ini. Ucapan terimakasih juga 
disampaikan kepada anggota tim pengabdian, mahasiswa Prodi Peternakan Faperta UNISKA yang telah membantu pelaksanaan kegiatan ini dan anggota PKK Ruhuy Rahayu Desa Bentok Kampung, Kecamatan Bati-Bati, Kabupaten Tanah Laut, Provinsi Kalimantan Selatan serta pihak - pihak terkait.

\section{DAFTAR PUSTAKA}

Nuun Marfu'ah dan Sugiarto. 2019. Sifat Organoleptik Telur Asin Ayam Kampung Yang Ditambahkan Rempah - Rempah. Jurnal Agrisains. 20(1): 26-31. ISSN: 1412-3657

Sari, F.R.E. 2013. Karakteristik Kimia dan Mikrobiologi serta Organoleptik Telur Asin dengan Lama Pengovenan yang Berbeda selama Penyimpanan. Skripsi. Institut Pertanian Bogor. Bogor

Suprapti, M.L. 2002. Pengawetan Telur. Kanisius. Yogyakarta

Theresia, M., Rosida I, Fitriani W. dan Jonathan D.A. 2014. Ilmu Teknologi Pangan Pembuatan Telur Asin. Jurusan Gizi Politeknik Kesehatan Kementrian Kesehatan Palangkaraya. Palangkaraya 